\title{
Genetic characterization of Toxoplasma gondii isolates from eared doves (Zenaida auriculata) in Brazil
}

\author{
Caracterização genética de isolados de Toxoplasma gondii de pombos (Zenaida auriculata) no Brasil \\ Luiz Daniel de Barros ${ }^{1 *}$; Alessandra Taroda ${ }^{1}$; Dauton Luiz Zulpo ${ }^{1}$; Ivo Alexandre Leme da Cunha ${ }^{1}$; Ana Sue Sammi ${ }^{1}$; \\ Sérgio Tosi Cardim; Ana Carolina Miura ${ }^{1}$; Chunlei $\mathrm{Su}^{2}$; Rosangela Zacarias Machado ${ }^{3}$; \\ Odilon Vidotto $^{1}$; João Luis Garcia ${ }^{1}$

\begin{abstract}
${ }^{1}$ Protozoology Laboratory, Department of Preventive Veterinary Medicine, Universidade Estadual de Londrina - UEL, Londrina, PR, Brazil

${ }^{2}$ Department of Microbiology, The University of Tennessee, Knoxville, TN, USA

${ }^{3}$ Department of Veterinary Pathology, School of Agrarian and Veterinary Sciences, Universidade Estadual Paulista "Julio de Mesquita Filho" - UNESP, Jaboticabal, SP, Brazil
\end{abstract}

Received April 22, 2014

Accepted July 25, 2014

\begin{abstract}
Eared doves (Zenaida auriculata), which are common in urban, rural and wild areas in many regions of Brazil, are frequently prey for domestic cats. Therefore Toxoplasma gondii isolates obtained from doves may reflect greater environmental diversity than those from other hosts. The aim of the present study was to evaluate T. gondii seroprevalence, isolate and genotype strains from $Z$. auriculata. Serum and tissue samples were collected from 206 doves for use in the modified agglutination test (MAT) and mouse bioassay. The prevalence of $T$. gondii antibodies in the doves was $22.3 \%$ (46/206), with titers ranging from 16 to 4096, and T. gondii strains were isolated from 12 of these doves. Five genotypes were detected by means of PCR-RFLP, including ToxoDB genotypes \#1, \#6, \#17 and \#65, and one genotype that had not previously been described (ToxoDB\#182). This was the first report on isolation of $T$. gondii from $Z$. auriculata. This study confirmed the genetic diversity of $T$. gondii isolates and the existence of clonal type II (ToxoDB genotype \#1) in Brazil.
\end{abstract}

Keywords: Toxoplasma gondii, eared doves, genotyping, PCR-RFLP, MAT, Biossay.

\section{Resumo}

Pombos silvestres (Zenaida auriculata), comuns em áreas urbanas, rurais e selvagens em muitas regióes do Brasil, são frequentemente predados por gatos domésticos. Sendo assim, os isolados de T. gondii obtidos de pombos podem refletir uma maior diversidade ambiental do que os outros hospedeiros. O objetivo do presente estudo foi avaliar a soroprevalência, isolar e genotipar T. gondii de Z. auriculata. Amostras de soro e tecido foram coletadas de 206 pombos para o teste de aglutinaçáo modificado (MAT) e o bioensaio em camundongos. A prevalência de anticorpos contra T. gondii em pombos foi 22,3\% (46/206), com títulos variando de 16 a 4096, e T. gondii foi isolado de 12 pombos. Cinco genótipos foram detectados por PCR-RFLP, incluindo os genótipos ToxoDB \#1, \#6, \#17, \#65 e um genótipo náo descrito anteriormente (ToxoDB\#182). Esse é o primeiro relato de isolamento de $T$. gondii de $Z$. auriculata. Este estudo também confirmou a diversidade dos isolados de $T$. gondii e a presença de tipo clonal II (ToxoDB \#1) no Brasil.

Palavras-chave: Toxoplasma gondii, pombos, genotipagem, PCR-RFLP, MAT, Bioensaio.

\footnotetext{
*Corresponding Author: Luiz Daniel de Barros, Laboratório de Protozoologia,

Departamento de Medicina Veterinária Preventiva, Universidade Estadual de Londrina - UEL, Rodovia Celso Garcia Cid, PR 445 Km 380, Campus Universitário, CEP: 86051-990, Londrina, PR, Brasil, e-mail: daniel_vetuel@ hotmail.com; jlgracia@uel.br
} 


\section{Introduction}

Toxoplasma gondii is an intracellular parasite that is distributed worldwide and can infect all warm-blooded animals, including mammals and birds (DUBEY et al., 2012). Human infections occur either from consumption of raw or undercooked meat containing tissue cysts or ingestion of food or water that is contaminated with sporulated oocysts (DUBEY \& JONES, 2008). Because it is difficult to estimate the oocyst contamination in the environment, free-range chickens have been used as indicators of soil contamination.

Other domestic and wild animals have also been used to isolate and genotype Toxoplasma strains in many parts of the world, including Brazil (YAI et al., 2009; DUBEY et al., 2011; PENA et al., 2011; CABRAL et al., 2013; MACIEL et al., 2014; SILVA et al., 2014). These studies have shown that the Brazilian T. gondii strains are highly diverse, in comparison with those from other parts of the world.

The eared dove (Zenaida auriculata, Des Murs, 1847) occurs from the Antilles to Tierra del Fuego. In Brazil, it is considered to be an important pest that causes significant agricultural losses, but it is also an important source of food for humans in some regions (TARODA et al., 2013). Because the feeding habits of eared doves are similar to those of chickens, we believe that these birds could be an important source for evaluating environmental contamination because of their abundance in many regions of Brazil and because they are a source of food for stray cats. Another reason is that this species of bird is endemic in South America, where they were living for a long time before the introduction of chickens to Brazil. T. gondii has been described in pigeons and other birds since the beginning of the last century, when Carini in São Paulo, Brazil, observed the parasite in liver and spleen smears from a rock dove (Columba livia) (DUBEY, 2002).

The aim of the present study was to evaluate the prevalence of anti-T. gondii antibodies and genetically characterize the isolates obtained from eared doves ( $Z$. auriculata) in Brazil.

\section{Materials and Methods}

\section{Sample collection and study area}

Two hundred and six free-ranging eared doves (Z. auriculata), including 97 males and 109 females, were caught in traps in Londrina ( $23^{\circ} 08^{\prime} 47^{\prime \prime}$ to $23^{\circ} 55^{\prime} 46^{\prime \prime} \mathrm{S} / 50^{\circ} 52^{\prime} 23^{\prime \prime}$ to $\left.51^{\circ} 19^{\prime} 11^{\prime \prime} \mathrm{W}\right)$, state of Paraná, southern Brazil, between January 2010 and June 2011. These birds were collected from three different areas: 140 birds from a soybean seed plant, 50 from the campus of the State University of Londrina and 16 from a dairy cattle farm. The present experiment was approved by the Animal Ethics Committee of the State University of Londrina (CEEA no. 70/08) and the Brazilian Institute of the Environment (IBAMA; SISBIO no. 16.428-1).

\section{Blood and tissue samples}

The birds were sacrificed in a $\mathrm{CO}_{2}$ chamber. They were then bled by means of cardiac puncture and the resultant serum samples were stored at $-20^{\circ} \mathrm{C}$ until further analysis. A pool of tissues of around $30 \mathrm{~g}$, comprising lung, liver, heart, pectoral muscle and brain tissues, was collected for bioassay in Swiss-Webster albino mice weighing approximately 20-25 g.

\section{Serological examination}

The RH strain was used for antigen production in our laboratory, for serological tests by means of the indirect immunofluorescent assay (IFA) and the modified agglutination test (MAT). The prevalence of anti- $T$. gondii antibodies in the doves was obtained from MAT, in accordance with the technique previously described by Desmonts and Remington (1980) and titers $\geq 16$ were considered to be positive.

\section{Mouse bioassay}

The pooled tissue from each bird, as described in section 2, was used to evaluate the presence of $T$. gondii cysts as described previously (DUBEY, 1998). Briefly, $30 \mathrm{~g}$ of brain, lung, liver, heart and pectoral muscle tissue were homogenized in a blender, in $150 \mathrm{ml}$ of saline solution $(0.14 \mathrm{M} \mathrm{NaCl})$, for 30 seconds. After homogenization, $150 \mathrm{ml}$ of pepsin solution $(0.78 \mathrm{~g}$ pepsin of 1:10000 biological activity, $1.5 \mathrm{~g}$ of $\mathrm{NaCl}$ and $2.1 \mathrm{ml}$ of $\mathrm{HCl}$, at $\mathrm{pH}$ 1.2) was added and incubated at $37^{\circ} \mathrm{C}$ for 1 hour. The homogenate was filtered through two layers of gauze and centrifuged at $1180 \mathrm{xg}$ for $10 \mathrm{~min}$. The supernatant was discarded and the sediment was suspended in $20 \mathrm{ml}$ of PBS (pH 7.2); $9 \mathrm{ml}$ of $1.2 \%$ sodium bicarbonate $(\mathrm{pH} 8.3)$ was then added and the mixture was centrifuged at $1180 \mathrm{xg}$ for $10 \mathrm{~min}$. The supernatant was discarded and the sediment was suspended in $3 \mathrm{ml}$ of antibiotic saline solution $(1,000 \mathrm{U}$ of penicillin and $100 \mu \mathrm{L}$ of streptomycin/ml of saline solution) and subcutaneously inoculated into three mice (1 $\mathrm{ml} /$ mouse).

\section{Examination of mice}

Impression smears from the lungs of the mice that died were fixed in methanol, stained with Giemsa and examined under a microscope. Blood samples were drawn from the mice that survived for 45 days after inoculation, and the brain of each mouse was examined under a microscope for $T$. gondii tissue cysts by squashing a portion of brain between a coverslip and a glass slide. Serum from each mouse was diluted at 1:16 and 1:64 and examined for $T$. gondii antibodies, using IFA, in accordance with the technique previously described (GARCIA et al., 2006). Mice with titers $\geq 16$ were considered to be positive.

\section{Genetic characterization of the T. gondii strains isolated}

Brain and lung tissue and peritoneal fluid from the bioassayed mice (i.e. from those in which tissue cysts and tachyzoites were observed) were used to extract DNA. DNA extraction was performed using a commercial kit (PureLink ${ }^{\mathrm{TM}}$ genomic DNA kit, Invitrogen ${ }^{\oplus}$, USA) in accordance with the manufacturer's 
instructions, and DNA was collected in a final volume of $50 \mu \mathrm{L}$. Strain genotyping was performed using multilocus PCR-RFLP with 11 genetic markers (SAG1, 5' and 3'SAG2, alt. SAG2, SAG3, BTUB, GRA6, c22-8, c29-2, L358, PK1 and Apico) as previously described (SU et al., 2006). DNA from eight reference strains (GT1, PTG, CTG, TgCgCa1, MAS, TgCatBr5, TgCatBr64 and TgRsCr1) was used as positive controls. Genotyping was performed following the method described previously (SU et al., 2010). The results were compared, identified and classified in accordance with the genotypes present in ToxoDB at http://toxodb.org/toxo/.

\section{Statistical analysis}

All the variables were analyzed by means of the chi-square test $\left(c^{2}\right)$ or Fisher's exact test, using the Epi Info software, version 6.04b (DEAN et al., 1994). P-values $\leq 0.05$ were considered to be significant.

\section{Results}

Antibodies against T. gondii were detected in 46 (22.3\%) of the 206 doves. The most frequent titer was 16 (13.5\%), followed by $64(3.3 \%), 256(3.0 \%), 1024(2.0 \%)$ and $4096(0.5 \%)$. In relation to the sex of the doves, $18.5 \%(18 / 97)$ of the males and $25.6 \%(28 / 109)$ of the females were seropositive, and there was no statistically significant difference between the groups ( $\mathrm{p}>0.05$ ). However, when the capture sites were compared, there was a statistically significant difference $(p<0.05)$, such that there was a higher rate of positivity among the doves from the university campus (56\%), compared with those from the soybean seed plant $(12.1 \%)$ or the dairy cattle farm $(6.2 \%)$ (Table 1$)$.

Using the mouse bioassay, T. gondii was isolated from 12 doves. The strains were named TgDoveBr1 to TgDoveBr12, according to the order of isolation (Table 2). The genotyping results for all of the markers are shown in Table 3. Five different genotypes were detected; four matched with the ToxoDB PCR-RFLP genotypes \#1, \#6, \#17 and \#65, and one genotype had not been described previously. Three of the isolates did not amplify all of the markers, so it was not possible to determine their genotypes.

\section{Discussion}

In the present study, we showed that the $T$. gondii seroprevalence in $Z$. auriculata was $22.3 \%$. Other studies in Brazil that used C. livia observed lower seroprevalence, which ranged from 0 to $5 \%$ (GODOI et al., 2010; SOUSA et al., 2010; LIMA et al., 2011). There was a statistically significant difference in the present study regarding the capture sites. Although the eared dove is a bird with the capacity to fly long distances and it has been shown to be able to fly daily distances of $117 \mathrm{~km}$ from breeding colonies (BUCHER \& BOCCO, 2009), the birds caught on the university campus had higher incidence of antibodies directed against T. gondii (56\%) than did those caught at the soybean seed plant (12.1\%) and the dairy cattle farm (6.2\%). Our hypothesis for this difference in occurrence between the capture sites is that some areas have high concentrations of cats, which could contribute towards environmental contamination. However, further studies should be conducted to confirm this hypothesis. Salant et al. (2009) found higher seropositivity in C. livia caught in rural areas, while Alvarado-Esquivel et al. (2011) reported greater seroprevalence in C. livia caught in areas near a zoo. This difference could be due to larger numbers of host animals, such as cats, rodents and birds, which may contribute towards parasite transmission.

When the sexes of the seropositive animals in our study were compared, there was no statistically significant difference. This was similar to the results observed previously for C. livia (TSAI et al., 2006; KARATEPE et al., 2011).

In the present study, two of the $12 T$. gondii strains were isolated from seronegative animals (MAT < 16), which possibly can be explained by previous findings of absence of detectable antibodies in chronically infected birds (MINEO et al., 2009). Although some isolates caused death in mice, we could not determine the virulence, because the dose for infection in mouse bioassays is unknown.

Genotypic characterization of the isolates obtained in the present study revealed the presence of four previously reported genotypes and one new genotype that had not previously been described, which has now been classified as ToxoDB\#182. In Brazil, genotypes \#6, \#17 and \#65 had previously been isolated from chickens, dogs and cats (DUBEY et al., 2002, 2003, 2007; PENA et al., 2006). The overlap in the genotypes between

Table 1. Presence of antibodies against Toxoplasma gondii in eared doves (Zenaida auriculata) using the modified agglutination test (MAT) and associations with sex and with capture site, in Londrina, Paraná State, Brazil.

\begin{tabular}{|c|c|c|c|c|}
\hline Variables & Positive $^{\mathrm{a}}(\%)$ & Negative (\%) & Total & P-value \\
\hline \multicolumn{5}{|l|}{ Sex } \\
\hline Male & $18(18.5)$ & $79(81.5)$ & 97 & \multirow{3}{*}{0.28} \\
\hline \multirow[t]{2}{*}{ Female } & $28(25.6)$ & $81(74.4)$ & 109 & \\
\hline & $46(22.3)$ & $160(77.7)$ & 206 & \\
\hline \multicolumn{5}{|l|}{ Capture site } \\
\hline University campus & $28(56.0)$ & $22(44.0)$ & 50 & $<0.001$ \\
\hline Soybean seed plant & $17(12.1)$ & $123(87.9)$ & 140 & \\
\hline \multirow[t]{2}{*}{ Dairy cattle farm } & $1(6.2)$ & $15(93.8)$ & 16 & \\
\hline & $46(22.3)$ & $160(77.7)$ & 206 & \\
\hline
\end{tabular}

${ }^{\mathrm{a} C u t-o f f}$ value: 16 . 
Table 2. Isolation of Toxoplasma gondii from eared doves (Zenaida auriculata) according to mouse bioassay.

\begin{tabular}{|c|c|c|c|c|c|c|c|}
\hline \multirow[b]{2}{*}{ Dove no. } & \multirow[b]{2}{*}{ Capture site $^{a}$} & \multirow[b]{2}{*}{ Isolate name } & \multirow[b]{2}{*}{ MAT titers } & \multicolumn{4}{|c|}{ Infectivity of $T$. gondii isolates to mice $(\mathrm{n}=3)$} \\
\hline & & & & $\begin{array}{c}\text { Mortality } \\
(\%)\end{array}$ & $\begin{array}{c}\text { Positive mice } \\
(\%)\end{array}$ & Tachyzoite & Tissue cyst \\
\hline 1 & UC & TgDoveBr1 & 64 & $2(66.6)$ & $2(66.6)$ & + & $+\mathrm{c}$ \\
\hline 6 & UC & TgDoveBr2 & 16 & $1(33.3)$ & $2(66.6)$ & + & - \\
\hline 12 & UC & TgDoveBr3 & 16 & $3(100)$ & $3(100)$ & + & - \\
\hline 13 & UC & TgDoveBr4 & 16 & $3(100)$ & $3(100)$ & + & - \\
\hline 14 & UC & TgDoveBr5 & 16 & $1(33.3)$ & $1(33.3)$ & + & - \\
\hline 36 & UC & TgDoveBr6 & 256 & $3(100)$ & $3(100)$ & + & $+\mathrm{c}$ \\
\hline 150 & SBP & TgDoveBr7 & 1024 & $2(66.6)$ & $3(100)$ & + & + \\
\hline 153 & SBP & TgDoveBr8 & $<16$ & 0 & $1(33.3)$ & - & + \\
\hline 155 & SBP & TgDoveBr9 & $<16$ & 0 & $1(33.3)$ & - & + \\
\hline 164 & SBP & TgDoveBr10 & 256 & $3(100)$ & $3(100)$ & + & - \\
\hline 185 & SBP & TgDoveBr11 & 1024 & $3(100)$ & $3(100)$ & + & - \\
\hline 200 & DCF & TgDoveBr12 & 1024 & $1(33.3)$ & $1(33.3)$ & + & - \\
\hline
\end{tabular}

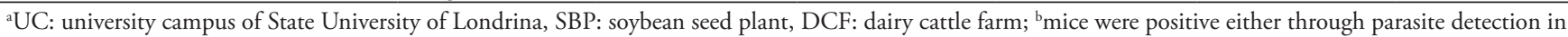
their tissues or through positive IFA test; ${ }^{c}$ mice re-inoculated with peritoneal fluid and lung homogenates that developed tissue cysts in the brain.

Table 3. PCR-RFLP genotypic profile from Toxoplasma gondii strains isolated from eared doves (Zenaida auriculata) from Londrina, Paraná State, Brazil.

\begin{tabular}{|c|c|c|c|c|c|c|c|c|c|c|c|c|}
\hline \multirow[b]{2}{*}{ Isolate } & \multicolumn{11}{|c|}{ Markers } & \multirow[b]{2}{*}{ Genotype } \\
\hline & SAG1 & SAG2 & $\begin{array}{c}\text { alt. } \\
\text { SAG2 }\end{array}$ & SAG3 & BTUB & GRA6 & c22-8 & c29-2 & L358 & PK1 & Apico & \\
\hline TgDoveBr1 & II/III & II & II & II & II & II & II & II & II & II & II & ToxoDB \# 1 \\
\hline TgDoveBr2 & II/III & II & II & II & II & II & II & II & II & II & II & ToxoDB \#1 \\
\hline TgDoveBr3 & I & nd & nd & III & II & II & II & III & II & II & I & nd \\
\hline TgDoveBr4 & nd & nd & nd & III & nd & III & nd & nd & nd & nd & nd & nd \\
\hline TgDoveBr5 & I & I & II & III & nd & III & $\mathrm{u}-1$ & nd & II & nd & II & nd \\
\hline TgDoveBr6 & I & III & III & III & III & III & III & I & I & I & III & ToxoDB \#182 - This study \\
\hline TgDoveBr7 & I & I & I & III & I & II & $\mathrm{u}-1$ & I & I & I & I & ToxoDB \#6 \\
\hline TgDoveBr8 & II/III & II & II & II & II & II & II & II & II & II & II & ToxoDB \# 1 \\
\hline TgDoveBr9 & II/III & II & II & II & II & II & II & II & II & II & II & ToxoDB \# 1 \\
\hline TgDoveBr10 & I & III & III & III & III & III & III & I & I & I & III & ToxoDB \#182 - This study \\
\hline TgDoveBr11 & $\mathrm{u}-1$ & I & II & III & III & III & $\mathrm{u}-1$ & I & I & III & I & ToxoDB \#17 \\
\hline TgDoveBr12 & I & I & II & III & III & III & $\mathrm{u}-1$ & I & I & III & I & ToxoDB \#65 \\
\hline
\end{tabular}

nd: not determined.

isolates from cats in the state of São Paulo and doves in the state of Paraná demonstrates that T. gondii genotypes are widespread across Brazil. Genotype \#1 is the clonal type II and is rare in Brazil but common in North America and Europe. The presence of type II has been reported in guinea fowl and cattle in Brazil (DUBEY et al., 2011; MACEDO et al., 2012). Previous studies on free-living pigeons (C. livia) in Brazil did not obtain T. gondii isolates (GODOI et al., 2010; LIMA et al., 2011). However, using the PCR-RFLP method, Alvarado-Esquivel et al. (2011) classified the isolate from the pigeon C. livia in Mexico as atypical, thus confirming the genotypic variability of non-European and American isolates.

\section{Conclusions}

To the authors' knowledge, this is the first study in which T. gondii was isolated and genetically characterized from $Z$. auriculata, a native wild dove that can be found in urban, rural and wild areas in many regions of Brazil. In this study, we identified a unique genotype and also clonal type II, thus showing that the genotypic composition of T. gondii strains in Brazil is highly diverse. Our data indicate that $T$. gondii genotypes are spread across the country and that doves can contribute towards disseminating them.

\section{Acknowledgements}

J.L. Garcia, O. Vidotto and R.Z. Machado are recipients of $\mathrm{CNPq}$ fellowships. We would like to thank the Coordination Office for Advancement of University-level Personnel (Coordenação de Aperfeiçoamento de Pessoal de Nível Superior, CAPES: AUXPEPARASITOLOGIA-1345/2011; and postdoctoral scholarship no. 10259/12-0) and the Research Support Foundation of the State of São Paulo (Fundação de Amparo à Pesquisa do Estado de São Paulo, FAPESP: no. 2010/01597-2) for financial support. 


\section{References}

Alvarado-Esquivel C, Rajendran C, Ferreira LR, Kwok OC, Choudhary S, Alvarado-Esquivel D, et al. Prevalence of Toxoplasma gondii infection in wild birds in Durango, Mexico. J Parasitol 2011; 97(5): 809-812. http://dx.doi.org/10.1645/GE-2844.1. PMid:21612413

Bucher EH, Bocco PJ. Reassessing the importance of granivorous pigeons as massive, long-distance seed dispersers. Ecology 2009; 90(8): 2321-2327. http://dx.doi.org/10.1890/08-2077.1. PMid:19739393

Cabral AD, Gama AR, Sodré MM, Savani ES, Galvão-Dias MA, Jordão LR, et al. First isolation and genotyping of Toxoplasma gondii from bats (Mammalia: Chiroptera). Vet Parasitol2013; 193(1-3): 100-104. http:// dx.doi.org/10.1016/j.vetpar.2012.11.015. PMid:23200751

Dean AG, Dean JA, Coulombier D, Brendel KA, Smith DC, Burton $\mathrm{AH}$, et al. Epi Info, version 6: a word processing, database, and statistics program for epidemiology on microcomputers. Atlanta: Centers for Disease Control and Prevention; 1994.

Desmonts G, Remington JS. Direct agglutination test for diagnosis of Toxoplasma infection: method for increasing sensitivity and specificity. J Clin Microbiol 1980; 11(6): 562-568. PMid:7000807.

Dubey JP. Refinement of pepsin digestion method for isolation of Toxoplasma gondii from infected tissues. Vet Parasitol 1998; 74(1): 75-77. http://dx.doi.org/10.1016/S0304-4017(97)00135-0. PMid:9493311

Dubey JP. A review of toxoplasmosis in wild birds. Vet Parasitol 2002; 106(2): 121-153. http://dx.doi.org/10.1016/S0304-4017(02)00034-1. PMid:12031816

Dubey JP, Jones JL. Toxoplasma gondii infection in humans and animals in the United States. Int J Parasitol 2008; 38(11): 1257-1278. http:// dx.doi.org/10.1016/j.ijpara.2008.03.007. PMid:18508057

Dubey JP, Graham DH, Blackston CR, Lehmann T, Gennari SM, Ragozo AM, et al. Biological and genetic characterisation of Toxoplasma gondii isolates from chickens (Gallus domesticus) from São Paulo, Brazil: unexpected findings. Int J Parasitol 2002; 32(1): 99-105. http://dx.doi. org/10.1016/S0020-7519(01)00364-2. PMid:11796127

Dubey JP, Graham DH, Silva DS, Lehmann T, Bahia-Oliveira LM. Toxoplasma gondii isolates of free-ranging chickens from Rio de Janeiro, Brazil: mouse mortality, genotype, and oocyst shedding by cats. $J$ Parasitol 2003; 89(4): 851-853. http://dx.doi.org/10.1645/GE-60R. PMid:14533703

Dubey JP, Sundar N, Gennari SM, Minervino AH, Farias NA, Ruas JL, et al. Biologic and genetic comparison of Toxoplasma gondii isolates in free-range chickens from the northern Pará state and the southern state Rio Grande do Sul, Brazil revealed highly diverse and distinct parasite populations. Vet Parasitol 2007; 143(2): 182-188. http://dx.doi. org/10.1016/j.vetpar.2006.08.024. PMid:16982151

Dubey JP, Passos LM, Rajendran C, Ferreira LR, Gennari SM, Su C. Isolation of viable Toxoplasma gondii from feral guinea fowl (Numida meleagris) and domestic rabbits (Oryctolagus cuniculus) from Brazil. J Parasitol 2011; 97(5): 842-845. http://dx.doi.org/10.1645/GE-2728.1. PMid:21506805

Dubey JP, Lago EG, Gennari SM, Su C, Jones JL. Toxoplasmosis in humans and animals in Brazil: high prevalence, high burden of disease, and epidemiology. Parasitology 2012; 139(11): 1375-1424. http://dx.doi. org/10.1017/S0031182012000765. PMid:22776427

Garcia JL, Navarro IT, Vidotto O, Gennari SM, Machado RZ, Luz Pereira AB, et al. Toxoplasma gondii: comparison of a rhoptry-ELISA with IFAT and MAT for antibody detection in sera of experimentally infected pigs. Exp Parasitol 2006; 113(2): 100-105. http://dx.doi.org/10.1016/j. exppara.2005.12.011. PMid:16458299

Godoi FS, Nishi SM, Pena HF, Gennari SM. Toxoplasma gondii: diagnosis of experimental and natural infection in pigeons (Columba livia) by serological, biological and molecular techniques. Rev Bras Parasitol Vet 2010; 19(4): 238-243. http://dx.doi.org/10.1590/S198429612010000400009. PMid:21184701

Karatepe M, Kılıç S, Karatepe B, Babür C. Prevalence of Toxoplasma gondii antibodies in domestic (Columba livia domestica) and wild (Columba livia livia) pigeons in Niğde region, Turkey. Turkiye Parazitol Derg 2011; 35(1): 23-26. http://dx.doi.org/10.5152/tpd.2011.06. PMid:21618187

Lima VY, Langoni H, Silva AV, Pezerico SB, Castro AP, Silva RC, et al. Chlamydophila psittaci and Toxoplasma gondii infection in pigeons (Columba livia) from São Paulo State, Brazil. Vet Parasitol 2011; 175(1-2): 9-14. http://dx.doi.org/10.1016/j.vetpar.2010.10.006. PMid:21055877

Macedo MF, Macedo CA, Ewald MP, Martins GF, Zulpo DL, Cunha IA, et al. Isolation and genotyping of Toxoplasma gondii from pregnant dairy cows (Bos taurus) slaughtered. Rev Bras Parasitol Vet 2012; 21(1): 74-77. http://dx.doi.org/10.1590/S1984-29612012000100016. PMid:22534951

Maciel BM, Moura RLS, Carvalho FS, Costa EA, Albuquerque GR. Identification and genetic characterization of a new Brazilian genotype of Toxoplasma gondii from sheep intended for human consumption. Parasitol Int 2014; 63(3): 567-570. http://dx.doi.org/10.1016/j. parint.2014.03.001. PMid:24631791

Mineo TW, Carrasco AO, Marciano JA, Werther K, Pinto AA, Machado RZ. Pigeons (Columba livia) are a suitable experimental model for Neospora caninum infection in birds. Vet Parasitol 2009; 159(2): 149153. http://dx.doi.org/10.1016/j.vetpar.2008.10.024. PMid:19027237

Pena HF, Soares RM, Amaku M, Dubey JP, Gennari SM. Toxoplasma gondii infection in cats from São Paulo state, Brazil: seroprevalence, oocyst shedding, isolation in mice, and biologic and molecular characterization. Res Vet Sci 2006; 81(1): 58-67. http://dx.doi. org/10.1016/j.rvsc.2005.09.007. PMid:16289158

Pena HF, Marvulo MF, Horta MC, Silva MA, Silva JC, Siqueira DB, et al. Isolation and genetic characterisation of Toxoplasma gondii from a red-handed howler monkey (Alouatta belzebul), a jaguarundi (Puma yagouaroundi), and a black-eared opossum (Didelphis aurita) from Brazil. Vet Parasitol 2011; 175(3-4): 377-381. http://dx.doi.org/10.1016/j. vetpar.2010.10.015. PMid:21055880

Salant H, Landau DY, Baneth G. A cross-sectional survey of Toxoplasma gondii antibodies in Israeli pigeons. Vet Parasitol 2009; 165(1-2): $145-$ 149. http://dx.doi.org/10.1016/j.vetpar.2009.06.031. PMid:19619946

Silva LA, Andrade RO, Carneiro ACAV, Vitor RWA. Overlapping Toxoplasma gondii genotypes circulating in domestic animals and humans in Southeastern Brazil. PLoS ONE 2014; 9(2): e90237. http://dx.doi. org/10.1371/journal.pone.0090237. PMid:24587295

Sousa E, Berchieri AJ, Pinto AA, Machado RZ, Carrasco AO, Marciano JA, et al. Prevalence of Salmonella spp. antibodies to Toxoplasma gondii, and Newcastle disease virus in feral pigeons (Columba livia) in the city of Jaboticabal, Brazil. J Zoo Wildl Med 2010; 41(4): 603-607. http:// dx.doi.org/10.1638/2008-0166.1. PMid:21370639

Su C, Zhang X, Dubey JP. Genotyping of Toxoplasma gondii by multilocus PCR-RFLP markers: a high resolution and simple method for identification of parasites. Int J Parasitol 2006; 36(7): 841-848. http:// dx.doi.org/10.1016/j.ijpara.2006.03.003. PMid:16643922 
Su C, Shwab EK, Zhou P, Zhu XQ, Dubey JP. Moving towards an integrated approach to molecular detection and identification of Toxoplasma gondii. Parasitology 2010; 137(1): 1-11. http://dx.doi. org/10.1017/S0031182009991065. PMid:19765337

Taroda A, Barros LD, Zulpo DL, Cunha IA, Paiva MC, Sammi AS, et al. Occurrence of gastrointestinal and renal helminths in Zenaida auriculata (Des Murs, 1847) trap-captured from Brazil. Rev Bras Parasitol Vet 2013; 22(3): 415-419. http://dx.doi.org/10.1590/S198429612013000300016. PMid:24142175
Tsai YJ, Chung WC, Lei HH, Wu YI. Prevalence of antibodies to Toxoplasma gondii in pigeons (Columba livia) in Taiwan. J Parasitol 2006; 92(4): 871. http://dx.doi.org/10.1645/GE-716R2.1. PMid:16995410 Yai LE, Ragozo AM, Soares RM, Pena HF, Su C, Gennari SM. Genetic diversity among capybara (Hydrochaeris hydrochaeris) isolates of Toxoplasma gondii from Brazil. Vet Parasitol 2009; 162(3-4): 332-337. http://dx.doi.org/10.1016/j.vetpar.2009.03.007. PMid:19375864 